\title{
Reconstruction of Large Defects in the Perineal Area Using Multiple Perforator Flaps
}

\author{
Ki Wook Sung, Won Jai Lee, In Sik Yun, Dong Won Lee \\ Institute for Human Tissue Restoration, Department of Plastic and Reconstructive Surgery, Yonsei University College of Medicine, Seoul, \\ Korea
}

Background Perineal defects are commonly encountered during the treatment of conditions such as malignancy, infectious disease, and trauma. Covering large defects in the perineal area is challenging due to its complicated anatomy and the need for functional preservation. Methods Fourteen patients who underwent reconstructive surgery with multiple perforator flaps for defects $>100 \mathrm{~cm}^{2}$ in the perineal area were included in this retrospective cohort study. Characteristics of the perforator flap operation and postoperative outcomes were reviewed. Results Reconstruction was performed using 2 perforator flaps for 13 patients and 3 perforator flaps for 1 patient. Internal pudendal artery perforator flaps were mainly used for covering the defects. The average defect size was $176.3 \pm 61.8 \mathrm{~cm}^{2}$ and the average size of each flap was $95.7 \pm 31.9 \mathrm{~cm}^{2}$. Six patients had minor complications, such as wound dehiscence and partial necrosis of the flap margin, which were corrected with simple revision procedures.

Conclusions Multiple perforator flaps can be used to achieve successful reconstructions of large perineal defects that are difficult to reconstruct with other coverage methods.

Keywords Reconstructive surgical procedures / Perforator flap / Perineum
Correspondence: Dong Won Lee Institute for Human Tissue Restoration, Department of Plastic and Reconstructive Surgery, Yonsei University College of Medicine, 50-1 Yonsei-ro, Seodaemun-gu, Seoul 03722 , Korea

Tel: $+82-2-2228-2215$

Fax: +82-2-393-6947

E-mail:xyphoss@yuhs.ac

Received: 22 Mar $2016 \bullet$ Revised: 18 Jun 2016 • Accepted: 9 Aug 2016

pISSN: 2234-6163 • elSSN: 2234-6171 • http://dx.doi.org/10.5999/aps.2016.43.5.446• Arch Plast Surg 2016;43:446-450

No potential conflict of interest relevant to this article was reported.

\section{INTRODUCTION}

Perineal defects are commonly encountered during the treatment of conditions such as malignancy in the perineal area, infectious disease, and trauma [1]. Radical treatments are usually indicated (e.g., wide excisions), which result in large, soft tissue defects. Successful reconstruction of soft tissue defects requires adequate skin coverage with well-vascularized tissue to fill the dead space [1]. Although small defects are relatively easy to cover using methods such as primary repair and skin grafting, coverage of large defects in the perineal area is challenging due to the complicated anatomy and the need for functional preservation [2]. The use of perforator flaps on soft tissue defects in the perineal area has been described by several surgeons [1-9]. Perforator flap surgery is now widely regarded as a beneficial reconstructive method because a good contour is laid out and there is no need to sacrifice the main source arteries and muscles [3]. However, large defects cannot be effectively covered with only a single perforator flap, as using a very large flap supplied by just one perforator may cause necrosis of the flap margin beyond the angiosome due to insufficient perfusion [10]. Because the perineal area has robust perforators $[3,4]$, multiple perforator flaps could be used for reconstruction of large and composite defects in the perineal area. This study investigated the use of multiple perforator flaps for reconstruction of soft tissue defects in the perineal area. 


\section{METHODS}

\section{Patients}

This retrospective cohort study included 14 patients with large defects in the perineal area. We defined a large defect as $>100$ $\mathrm{cm}^{2}$. Patients presented with large and composite defects in the perineal area and underwent reconstructive surgery with multiple perforator flaps. The average age of the patients was 65 years (range, 34-84 years). The causes of defect were the following: 9 cases of extramammary Paget disease, 1 case of Bowen disease, 1 case of squamous cell carcinoma, 1 case of malignant melanoma, 1 case of dermatofibrosarcoma, and 1 case of Fournier gangrene. We reviewed the defect size and flap dimensions, and applied perforator flaps depending on the defect site and complications. The average follow-up period was 11.5 months (range, 1-48 months), and postoperative outcomes were evaluated at the outpatient clinic.

\section{Surgical technique}

All surgical procedures were performed under general anesthe- sia. Patients were placed in a lithotomy or prone position. First, we meticulously removed the diseased tissue. Perforators around the defect were identified and marked using a hand-held Doppler. After identifying several perforators situated around the defect, multiple perforators were chosen, and the flaps were designed. The distance between the location of the perforators and the distal edge of the defect were measured and used to determine the lengths of the flaps. Flap length and width were made to be slightly larger than the defect area. After skin incision of the designed flaps, subfascial dissection was performed until the previously marked perforators were encountered. We did not perform vascular skeletonization of the perforators to prevent the risk of iatrogenic injury and vascular spasm. After the flaps were elevated and the defect was covered without tension, primary closure was performed at the donor site. Finally, the flaps were inset with negative suction drains.

\section{RESULTS}

Of the 14 patients, 13 underwent reconstruction using 2 perfoTable 1. Patient demographic, treatment, and outcome data

\begin{tabular}{|c|c|c|c|c|c|c|c|c|c|}
\hline Case & Sex & $\begin{array}{l}\text { Age } \\
\text { (yr) }\end{array}$ & Cause of defect & $\begin{array}{l}\text { Defect } \\
\text { size }\left(\mathrm{cm}^{2}\right)\end{array}$ & $\begin{array}{l}\text { No. of } \\
\text { flaps }\end{array}$ & $\begin{array}{l}\text { Used perforator } \\
\text { flaps }\end{array}$ & $\begin{array}{l}\text { Flap size } \\
\left(\mathrm{cm}^{2}\right)\end{array}$ & $\begin{array}{l}\text { Follow-up } \\
\text { period (mo) }\end{array}$ & Complication \\
\hline 1 & Female & 56 & Extramammary Paget disease of the vulva & 195 & 2 & $\begin{array}{l}\text { Internal pudendal artery } \\
\text { perforator flap } \times 2\end{array}$ & 120,91 & 2 & Wound dehiscence \\
\hline 2 & Female & 58 & Extramammary Paget disease of the vulva & 240 & 2 & $\begin{array}{l}\text { Internal pudendal artery } \\
\text { perforator flap } \times 2\end{array}$ & 160,160 & 5 & Flap margin necrosis \\
\hline 3 & Female & 63 & Extramammary Paget disease of the vulva & 168 & 2 & $\begin{array}{l}\text { Internal pudendal artery } \\
\text { perforator flap } \times 2\end{array}$ & 84,91 & 2 & Flap margin necrosis \\
\hline 4 & Female & 69 & Extramammary Paget disease of the vulva & 170 & 2 & $\begin{array}{l}\text { Internal pudendal artery } \\
\text { perforator flap } \times 2\end{array}$ & 102,84 & 33 & None \\
\hline 5 & Female & 75 & Extramammary Paget disease of the vulva & 195 & 2 & $\begin{array}{l}\text { Internal pudendal artery } \\
\text { perforator flap } \times 2\end{array}$ & 91,102 & 7 & None \\
\hline 6 & Female & 75 & Extramammary Paget disease of the vulva & 195 & 2 & $\begin{array}{l}\text { Internal pudendal artery } \\
\text { perforator flap } \times 2\end{array}$ & 104,91 & 1 & None \\
\hline 7 & Female & 78 & Extramammary Paget disease of the vulva & 120 & 2 & $\begin{array}{l}\text { Internal pudendal artery } \\
\text { perforator flap } \times 2\end{array}$ & 84,120 & 35 & Flap margin necrosis \\
\hline 8 & Female & 69 & Extramammary Paget disease of the vulva & 108 & 2 & $\begin{array}{l}\text { Internal pudendal artery } \\
\text { perforator flap } \times 2\end{array}$ & 91,45 & 9 & None \\
\hline 9 & Male & 84 & Extramammary Paget disease of the anus & 104 & 2 & $\begin{array}{r}\text { Inferior gluteal artery } \\
\text { perforator flap } \times 2\end{array}$ & 54,63 & 1 & None \\
\hline 10 & Female & 34 & Bowen disease of the vulva & 144 & 2 & $\begin{array}{l}\text { Internal pudendal artery } \\
\text { perforator flap } \times 2\end{array}$ & 80,80 & 9 & None \\
\hline 11 & Female & 73 & Squamous cell carcinoma of the vulva & 144 & 2 & $\begin{array}{l}\text { Internal pudendal artery } \\
\text { perforator flap } \times 2\end{array}$ & 78,60 & 4 & Flap margin necrosis \\
\hline 12 & Female & 38 & Malignant melanoma of the vulva & 120 & 2 & $\begin{array}{l}\text { Internal pudendal artery } \\
\text { perforator flap } \times 2\end{array}$ & 64,64 & 4 & None \\
\hline 13 & Male & 74 & $\begin{array}{l}\text { Fournier gangrene of the perineal to coccyx } \\
\text { area and sacral pressure sore }\end{array}$ & 325 & 3 & $\begin{array}{l}\text { Internal pudendal artery } \\
\text { perforator flap } \times 2 \\
\text { Superior gluteal artery } \\
\text { perforator flap }\end{array}$ & $\begin{array}{c}144,153 \\
66\end{array}$ & 48 & Flap margin necrosis \\
\hline 14 & Female & 63 & Dermatofibrosarcoma of the vulva & 240 & 2 & $\begin{array}{l}\text { Internal pudendal artery } \\
\text { perforator flap } \\
\text { Deep inferior epigastric } \\
\text { artery perforator flap }\end{array}$ & $\begin{array}{l}105 \\
144\end{array}$ & 2 & None \\
\hline
\end{tabular}


rator flaps each, and 1 underwent reconstruction using 3 perforator flaps. The average defect size was $176.3 \pm 61.8 \mathrm{~cm}^{2}$, and the average size of each flap was $95.7 \pm 31.9 \mathrm{~cm}^{2}$. An internal pudendal artery perforator (IPAP) flap was mainly used for inguinoperineal defects. Inferior gluteal artery perforator (IGAP) flaps and pedicled deep inferior epigastric perforator (DIEP) flaps were used as secondary flaps. Primary closure of the donor site was achieved for all patients.

Eight surgeries had successful outcomes without any complications. There were 5 cases of partial necrosis of the flap margin and
1 case of wound dehiscence. However, a simple revision procedure was sufficient to achieve recovery for these cases. There were no cases of total flap necrosis or donor site complications (Table 1).

\section{Case 1 (patient 4)}

A 69-year-old woman with no previous medical history was diagnosed with extramammary Paget disease on the vulva area. A $170 \mathrm{~cm}^{2}$ large defect was noted after a wide excision was done by the gynecologist. We covered the defect with bilateral IPAP flaps $\left(102 \mathrm{~cm}^{2}\right.$ and $84 \mathrm{~cm}^{2}$, respectively). Negative suction drains

\section{Fig. 1. A case using bilateral IPAP flaps}

(A) Intraoperative view of a $170-\mathrm{cm}^{2}$ defect on the perineal area and design of the bilateral IPAP flaps. (B) Immediate postoperative view. Flaps were rotated and inset without tension, and primary closure of the donor site was performed. (C) Postoperative view 33 months after surgery. IPAP, internal pudendal artery perforator.
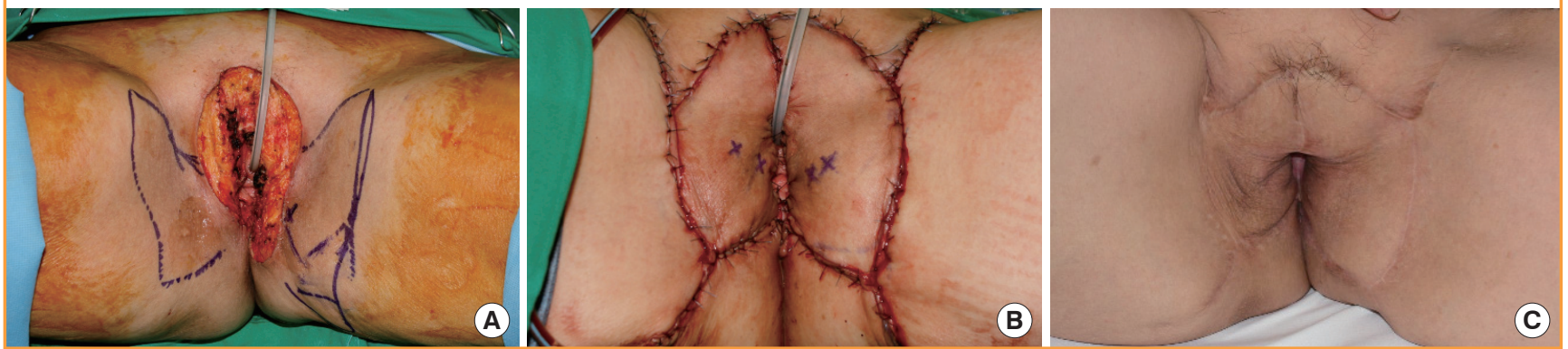

Fig. 2. A case using bilateral IPAP and SGAP flaps

(A) Intraoperative view of a $325-\mathrm{cm}^{2}$ defect in the perineal area and sacrum. (B) Design of bilateral IPAP flaps. (C) Intraoperative design of the SGAP flap and transposed right IPAP flap for coverage of a coccyx and sacral defect. (D, E) Immediate postoperative view. Flaps were rotated and inset without tension, and primary closure of the donor site was performed. (F) Postoperative view 44 months after surgery. IPAP, internal pudendal artery perforator; SGAP, superior gluteal artery perforator.
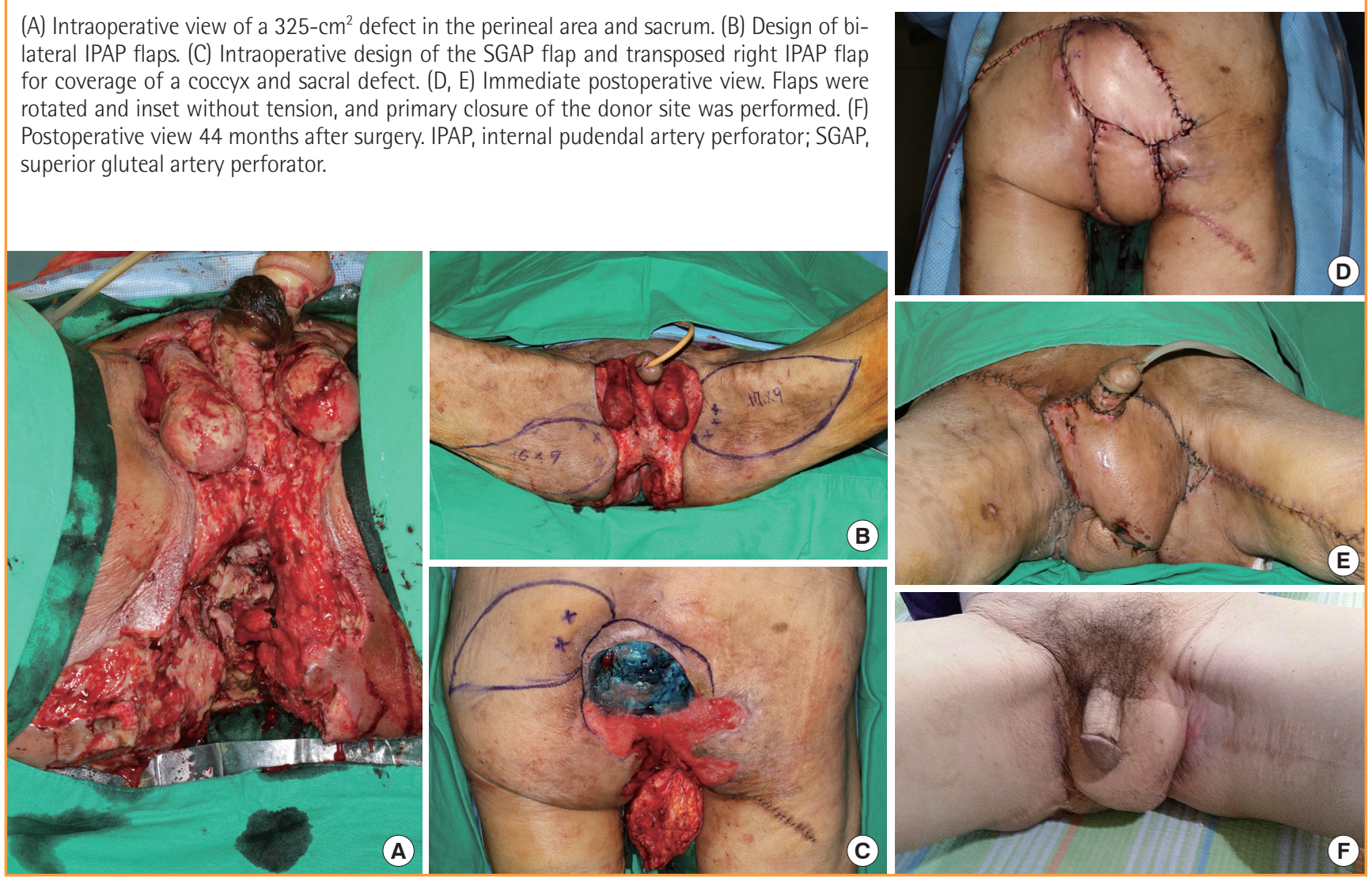
were inserted and primary closure of the donor sites was performed. The patient was put on bed rest in the lithotomy position for 5 days; ambulation was permitted after removing the urinary catheter 7 days after the operation. The patient was discharged from the hospital without any complications (Fig. 1).

\section{Case 2 (patient 13)}

A 74-year-old man with a history of pneumoconiosis was diagnosed with Fournier gangrene. In addition, a pressure sore had occurred on his sacrum due to long-term bed rest in the intensive care unit. We performed reconstruction to cover a $325-\mathrm{cm}^{2}$ perineal-to-sacral defect after extensive debridement. The perineal-to-coccyx defect was covered by bilateral IPAP flaps (144 $\mathrm{cm}^{2}$ and $153 \mathrm{~cm}^{2}$, respectively). The bilateral IPAP flaps were stabilized after 7 days of bed rest in the lithotomy position, and a second operation for the sacral sore was then performed. The sacral area was covered with a right superior gluteal artery perforator flap $\left(66 \mathrm{~cm}^{2}\right)$. Primary closure of the donor site was performed. The patient was discharged from the hospital without any complications (Fig. 2).

\section{Case 3 (patient 14)}

A 63-year-old woman with no previous medical history underwent a wide excision of a dermatofibrosarcoma in the perineal area. After the wide excision, a $240-\mathrm{cm}^{2}$ defect was noted. A right IPAP flap $\left(105 \mathrm{~cm}^{2}\right)$ and a DIEP flap $\left(144 \mathrm{~cm}^{2}\right)$ were used for reconstruction. Primary closure of the donor site was performed. The patient was put on bed rest in the lithotomy position for 5 days and ambulation was permitted after removing the urinary catheter 7 days after the operation. The patient was discharged from the hospital without any complications (Fig. 3).

\section{DISCUSSION}

Soft tissue defects in the perineal area are complex and 3-dimensional. For large defects, primary closure or closure by secondary intention cannot cover the defect. Although skin grafts could be a solution, these have their own limitations, such as insufficient volume, vulnerability to trauma, and postoperative contracture [5]. Functional outcomes should be considered when reconstructing the perineal area $[5]$. To achieve effective reconstruction, the flap should not be bulky and should provide excretory, sexual, and protective sensations [4].

\section{Fig. 3. A case using IPAP and DIEP flaps}

\begin{abstract}
(A) Preoperative view of dermatofibrosarcoma in the perineal area. (B) Intraoperative view of a $240-\mathrm{cm}^{2}$ defect after wide excision. (C, D) Design of a right IPAP flap and a DIEP flap. (E) Immediate postoperative view. Flaps were rotated and inset without tension, and primary closure of the donor site was performed. (F) Postoperative view 2 months after surgery. IPAP, internal pudendal artery perforator; DIEP, deep inferior epigastric perforator.
\end{abstract}
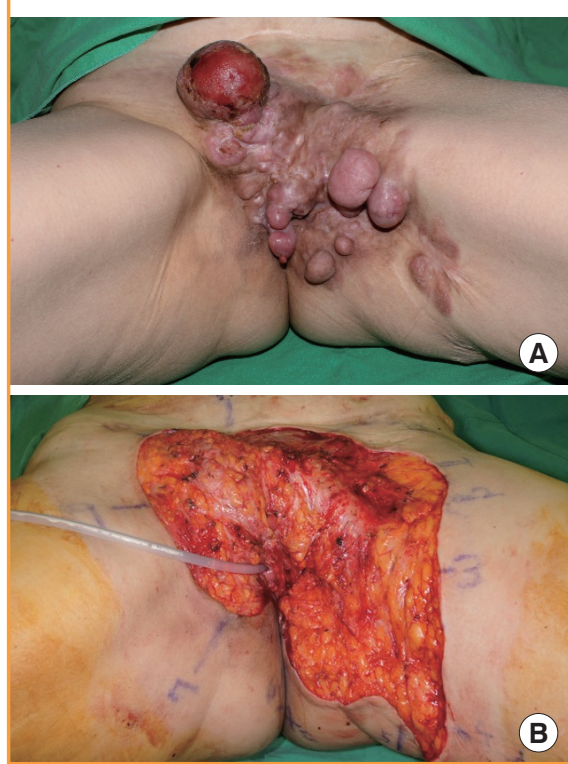

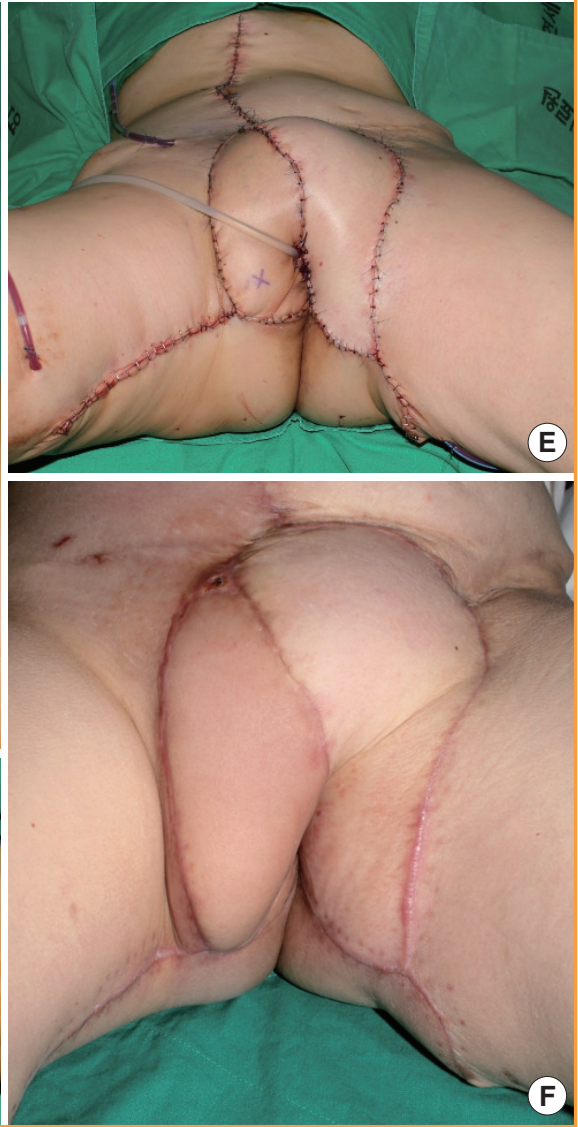


For successful reconstruction of perineal defects, various surgical options have been described $[1,6]$. Conventional methods, such as gracilis muscle flaps, gluteus muscle flaps, and rectus abdominis myocutaneous flaps are useful options for covering perineal defects $[1,6]$. Free flaps can be another option [7]. However, conventional flaps and free flaps sacrifice the major source blood vessels and muscles, and may cause donor site morbidity [3]. These flaps are usually bulky and often require secondary procedures such as defatting or resurfacing $[1,3]$. Anatomical and clinical studies of various perforators have been reported recently $[3,4]$, and perforator flap surgery has become a popular method for perineal area reconstruction due to the great number of perforators in the perineal area. Sinna et al. [6] found 3-5 perforators within the $6 \mathrm{~cm}$ area between the medial border of the gluteus maximus and the vulva. We have used perforators arising from the internal pudendal artery in many cases of perineal reconstruction. Our results indicate that various shapes, directions, and sizes of flaps using IPAP are possible. An IGAP flap or a pedicled DIEP flap can be used if needed for perineal area reconstruction.

In perineal reconstruction, there are several advantages to using multiple perforator flaps instead of a single perforator flap. First, defects that are difficult to cover with a single perforator flap are easier to cover with multiple perforator flaps. Second, tension-free closure of donor sites can easily be achieved by using 2 or 3 perforator flaps instead of 1 large perforator flap. Third, because the perineum is a symmetric organ, multiple perforator flaps provide better aesthetic outcomes by covering each side of the organ separately. Fourth, by placing the respective perforator flaps on the inguinal or gluteal fold, one can both hide the scars and add aesthetic value by allowing tension free closure of the donor site.

By using robust perforators distributed on the perineal area (mainly the IPAP), not only was successful defect coverage achieved but the aesthetics were also satisfactory for cases in this study. In addition to the IPAP flap, IGAP and pedicled DIEP flaps were also used. In order to cover large defects on the perineal area, these flaps can be used concurrently [7] or combined with conventional flaps [8]. Therefore, using multiple perforator flaps for the reconstruction of large defects in the perineal area can serve as an effective alternative option.
We successfully used multiple perforator flaps to reconstruct large perineal defects with only minor complications. As mentioned above, Niranjan [4] has noted that perineal reconstruction should not be bulky, should protect sensation, and should maintain excretory and sexual functions. Unfortunately, functional evaluations (gait, urination, sensitivity, and sexual factors) were not completed for our study. Studies that compare the functional results of multiple perforator flaps with conventional flaps are needed in the future.

\section{REFERENCES}

1. Mughal M, Baker RJ, Muneer A, et al. Reconstruction of perineal defects. Ann R Coll Surg Engl 2013;95:539-44.

2. Sakai S, Soeda S, Haibara H. A subcutaneous pedicle flap for perineal reconstruction. Ann Plast Surg 1989;22:440-3.

3. Kim JT, Ho SY, Hwang JH, et al. Perineal perforator-based island flaps: the next frontier in perineal reconstruction. Plast Reconstr Surg 2014;133:683e-687e.

4. Niranjan NS. Perforator flaps for perineal reconstructions. Semin Plast Surg 2006;20:133-44.

5. Yun IS, Lee JH, Rah DK, et al. Perineal reconstruction using a bilobed pudendal artery perforator flap. Gynecol Oncol 2010;118:313-6.

6. Sinna R, Qassemyar Q Benhaim T, et al. Perforator flaps: a new option in perineal reconstruction. J Plast Reconstr Aesthet Surg 2010;63:e766-74.

7. Ahn DK, Kim SW, Park SY, et al. Reconstructive strategy and classification of penoscrotal defects. Urology 2014;84: 1217-22.

8. Schmidt VJ, Horch RE, Dragu A, et al. Perineal and vaginal wall reconstruction using a combined inferior gluteal and pudendal artery perforator flap: a case report. J Plast Reconstr Aesthet Surg 2012;65:1734-7.

9. Lee SH, Rah DK, Lee WJ. Penoscrotal reconstruction with gracilis muscle flap and internal pudendal artery perforator flap transposition. Urology 2012;79:1390-4.

10. Rozen WM, Grinsell D, Koshima I, et al. Dominance between angiosome and perforator territories: a new anatomical model for the design of perforator flaps. J Reconstr Microsurg 2010;26:539-45. 